\title{
Identification of e-Governance Indicators for Measuring Smart Governance in Bandung City
}

\author{
Mochamad Yudha Febrianta, ST. \\ School of Economic and Business \\ Telkom University (Tel-U) \\ Bandung, Indonesia \\ +6281321202131 \\ yudhafeb@telkomuniversity.ac.id
}

\author{
Dra. Indrawati, M.M., Ph.D. \\ School of Economic and Business \\ Telkom University (Tel-U) \\ Bandung, Indonesia \\ +6281321922742 \\ indrawati@telkomuniversity.ac.id
}

\author{
Dr. Ir. Husni Amani, M.M, M.Sc. \\ School of Economic and Business \\ Telkom University (Tel-U) \\ Bandung, Indonesia \\ +62811214218 \\ husni@telkomuniversity.ac.id
}

\begin{abstract}
Bandung became the center of urbanization in Indonesia, from 43 million people in West Java urbanization centered in the capital of West Java, namely the city of Bandung. The high level of urbanization becomes the main problem in Bandung; Problems arises, how to improve the service of Bandung City Government in managing and solving the issues arising from the impact of urbanization. Smart City is a solution to improve the function of Bandung City Government, especially in the field of Smart Governance to the Government of Bandung City Good Governance. To measure whether the city of Bandung has implemented Smart Governance required identification of dimensions and indicators that determine whether Bandung has implemented Smart Governance. Smart Governance dimensions and indicators are obtained from literature studies and then confirmed to respondents who have the expertise and having experience in the field of Smart City. The interview and focus group discussions conducted to the respondents, and the researcher will grasp the main variables and indicators which is coming up to determine whether Bandung City is implementing Smart Governance in proper ways. The new proposed model will come up from the interview and focus group discussion result. Also, there will be statements in measuring the readiness of Smart Governance implementation in Bandung or other cities.
\end{abstract}

Keywords-urbanization, smart city, smart governance, good governance, Bandung city municipal, e-governance

\section{INTRODUCTION}

In 2013, the Global Standards Initiative on the Internet of Things (IoT-GSI) defined the Internet of Things (IoT) as the infrastructure of the information society. IoT allows an object to be detected and controlled remotely through an existing network infrastructure to be integrated directly from the real world with a computer-based system that will result in increased efficiency, accuracy, and economic benefits. By 2020, Gartner claims that there will be more than 26 billion devices to be connected [1]. Research from Ericsson stated that $93 \%$ of Telecom Operators mention that IoT would play a significant role to monetize $5 \mathrm{G}$ technology which will develop after the implementation of $4 \mathrm{G}$ LTE technology at this time, so this makes the Internet of Things is a technology that will become a trend and will grow big in the future front [2].

IoT is expected to offer further connectivity between devices, systems, and services so that it can be possible to communicate between machine-to-machine (M2M) and can link multiple protocols, domains, and applications. The interconnection of these connected devices (including smart objects), is expected to be a mediator that can automatically control all areas of the urban community, even further developed for further applications such as smart grid and also cover Smart City area.

According to the United Nations states that there is an increase in the number of people who are urbanizing in Indonesia and the tendency that number will increase in the following years [3].

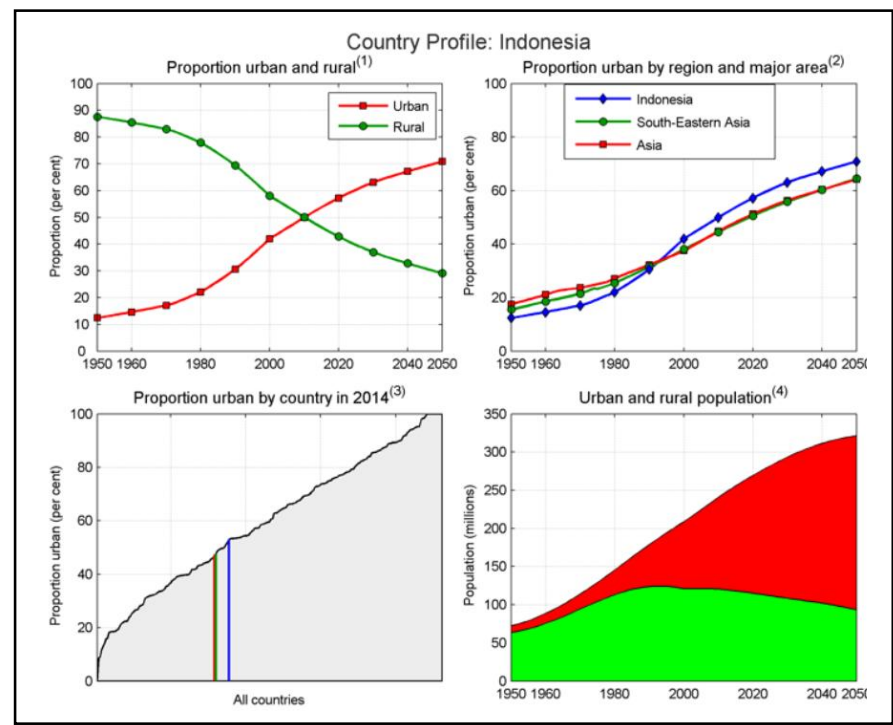

Figure 1. Profile of urbanization in Indonesia Source: (Department of Economic and Social Affairs, 2014)

Figure 1 shows that there are facts related to the increase of urbanization in Indonesia, which is relatively high when it compared with other countries in Asia and Southeast Asia region. So with a high level of urbanization would certainly cause potential problems in major cities in Indonesia.

According to data from Internet World Statistics in 2015, Indonesia ranks eighth in the country with the world's largest Internet user. The high internet usage reflects the climate of information disclosure and public acceptance of technological developments and changes to the information society [4]. 
According to a survey conducted by APJII, as many as 132.70 million Indonesians are internet users [5]. One of them in West Java Province as the highest population in Indonesia according to [6] in 2010 was ranked first of 34 provinces in Indonesia with the number is more than 43 million population. So that the area of West Java with the capital of Bandung became an area with a potential number of Internet users are high in Indonesia.

Survey of internet user behavior by APJII Indonesia states that $25.30 \%$ of Indonesia's population or about 31.30 million Indonesians use the internet to update information. Then 27.60 million Indonesians use internet related jobs, and the rest use the internet to fill leisure time, socialization, related education, entertainment, and to do business or looking for goods. Based on the survey, approximately $90.40 \%$ or about 119.90 million Indonesians who use the internet agree that social media can be used to disseminate government policies to the public [5].

Mentioned in the Pikiran Rakyat newspaper [7] in this case in West Java, especially in the city of Bandung, the internet can be used as a medium to improve service to the community as shown in Figure 2. Appropriate vision of Bandung is "Comfortable and Prosperous", and the mission of Bandung City" Presenting accountable, clean and servicing governance", Bandung Mayor Ridwan Kamil stated that it would like to show progress in areas where Smart City is doing a lot to improve service to society, bureaucratic reform, and budgetary savings.

Figure 2. Social Media for Socialization Activities

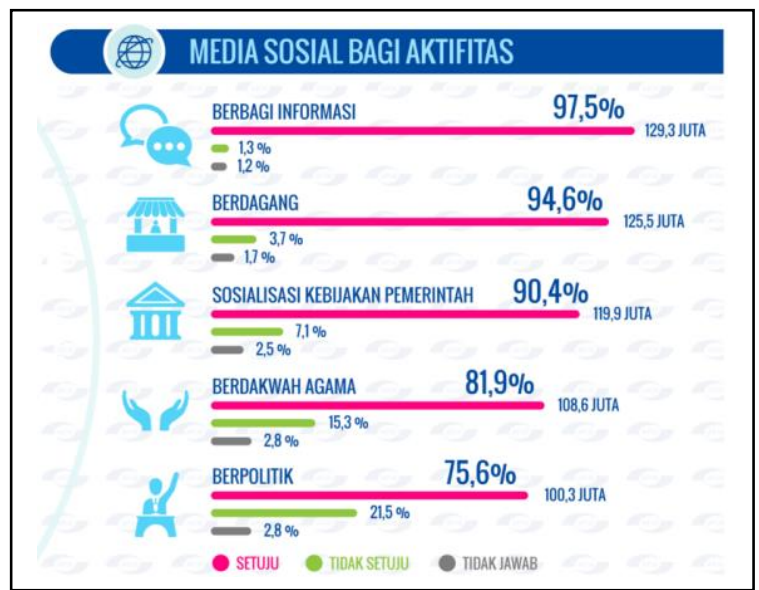

Government Policy

Source: (APJII, 2016)

Bureaucratic reforms conducted by Ridwan Kamil [8] in providing solutions to problems in Bandung that he disclosed has managed to become a breakthrough during his leadership is as follows:

1. An opening of the auction office for two Unit's Head.

2. The launching of the Camat's report card.

3. The launching of the report for the village leader.

4. The launching of the SIP (Government Information System).

5. The launching of the Grants/Bansos online.

6. The removing of the field tax collection team.

7. The launching of The New Student Acceptance Mechanism and Information System (PPDB).

\section{Establish TABG (Building Expert Team).}

9. The launching of the anti-corruption program/gratification.

10. To fixing the report of the public service.

11. The launching of e-Musrenbang.

12. The launching of REPORT apps.

13. The first city to use Twitter in all duty.

14. The launching of a quick patch reaction unit.

15. The launching of a 24-hour community health center for the poor.

16. The launching of inpatient clinics for chronic illness.

17. Increase goods/services via e-catalog.

18. Change the doctor's queue at RSUD Ujung Berung via SMS.

19. Smart City Launching.

One of the innovations of bureaucratic reformation from Ridwan Kamil is to make Bandung City Government under his leadership to apply Bandung Smart City consisting of five (5) milestones roadmap as stated in the presentation of Ridwan Kamil [9], namely Infrastructure, Capacity Building, Open \& Smart Government, Citizen Engagement, and Bandung Technopolis.

Regarding news from Pikiran Rakyat [7], Indonesia Smart City Forum (Forum Kota Cerdas Indonesia) initiated by the Government of Bandung was being held at The Trans Luxury Hotel Bandung on Friday (02/09/2016). This forum is a place to collaborate and share inter-district / municipal software for Indonesia to accelerate information and technology-based development. "Almost 70 percent of the problems we did not have access now can be solved," said Ridwan Kamil, when meeting reporters after the opening of Indonesia Smart City Forum (ISFC) 2016 at Trans Luxury Hotel, Bandung, West Java, Friday (2/9 / 2016). According to Kang Emil, technologybased public services greatly facilitate the settlement, especially in the face of complaints from the public. Where the SKPD is required to have social media so that it can manipulate community reports immediately, Ridwan Kamil also said infrastructure projects could be monitored directly through the implementation of Smart City system. Besides, the performance of local government officials can be evaluated to fit more optimally. Through the existing Smart City system, two subdistricts, and four heads of villages have been dismissed for their poor performance [10].

The software sharing was confirmed in Memorandum of Understanding witnessed by the Minister of Administrative Reform and Bureaucratic Reform Asman Abnur. "The technology can bring Indonesia into a great country," said Ridwan Kamil.

Ridwan Kamil states as an example, Bandung has 320 software, adapted to the problems of the city. Cooperation with other parties to produce the software spent Rp 40 billion. "But through e-Budgeting Software, we have been able to detect a wasteful budget, hidden behind the names of long and thick nomenclature with almost 1,200 of our activities deleted with a value of Rp 1 trillion." 
Minister for Administrative and Bureaucratic Reform Asman Abnur said he would issue a decree, the Smart City forum is mandatory for all districts and will be held annually. "This is the most practical learning forum not to research, let alone a comparative study, coming to Japan, to Singapore what the fare is. This movement cuts half the progress journey". Smart City is in line with two presidential instructions focusing on improving public services and implementing e-Government Software and e-Budgeting.

According to Ardisasmita's, the approach taken by Ridwan Kamil as a mayor is a community-based approach and mutually benefitted cooperation. Many parties are invited to collaborate to realize Bandung Smart City ranging from community, university, private, to foreign countries to become sister city or city that invited to cooperate intensively in various sectors [11].

In a study by Frost \& Sullivan [12], through the research of so many Smart City projects and initiatives globally it has formulated and identified eight aspects of Smart City: Smart Governance, Smart Energy, Smart Building, Smart Mobility, Smart Infrastructure, Smart Technology, Smart Healthcare and Smart Citizen as shown in Figure 3 below.

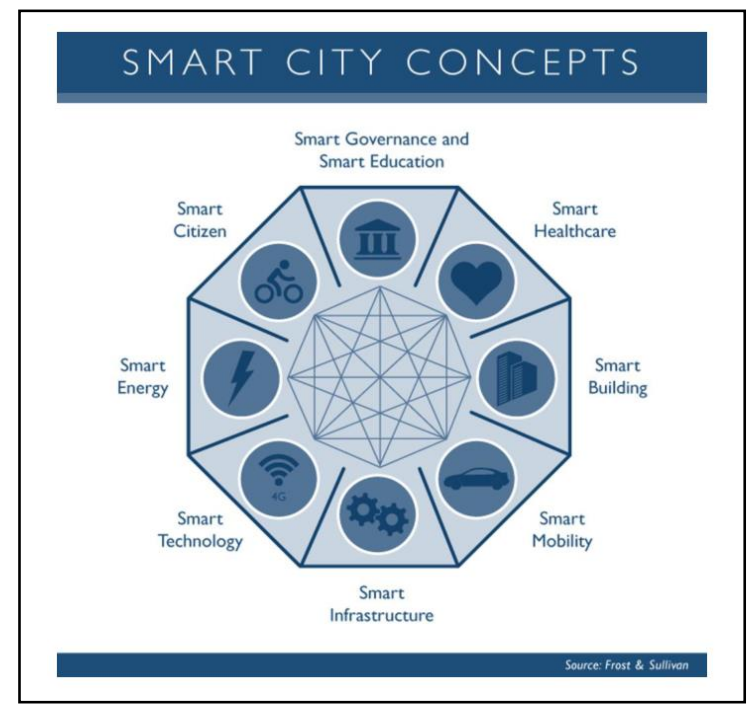

Figure 3. Smart City Concepts according to Frost \& Sullivan

Source: (Singh, 2014)

In Kardos's study, it is stated that "Governance has traditionally connoted the act or process of governing", but modern theories have expanded the connotation. Focusing on a large variety of instruments designed to alter and channel the behavior of individual and collective actors (Loorbach, 2007 ; Pierre and Peters, 2000; Adger and Jordan, 2009) As stated by Lafferty (2004), governance has been available for influential social influences in preordained directions" [13]. Smart Governance is the most important part of Smart City because the City Government is a major stakeholder with many instruments designed to direct the behavioral habits of individuals or groups of actors who play a role in urban society. The city government also needs to influence the social changes in society that lead to urban strategy predetermined or pre-planned.

\section{RESEARCH OBJECTIVES AND QUESTIONS}

According to Scuotto's research, in today's digital era a city is considered capable of performing its tasks relevant to provide innovation direction to be able to manage in several vital areas such as health, environment and Information Communication Technologies (ICTs) [14]. The city is known as Smart City, which involves the development of open and user-based innovation ecosystems to improve innovation and improve people's lives [15]. Smart City focuses on efforts to transform rural and urban areas [14].

Implementation of Smart City in Indonesia is needed because this platform is not only for public services but also for business, administration, management in the field of security so that with this platform all activities can be improved effectiveness and efficiency as mentioned by Komunitas Smart City Indonesia [16].

According to the Smart City ID Community, in this society is an essential part of the creation of Smart City with the habits that used to be abandoned. Smart City impact the quality of life of citizens to make a city more efficient, safe, and comfortable. Communities are also required to participate in the management and administration of the city and become an active city user [16].

To carry out the program is undoubtedly needed in-depth analysis of the factors or indicators that support the success in implementation. Government, in this case, Bandung City Government, as the capital of West Java, would require identification to assess how Smart Governance can be implemented in the city of Bandung. This study is expected to be used as a reference in determining the criteria of indicators to assess the application of Smart City, especially in the field of Smart Governance in the city of Bandung.

Development in the use of Information Systems is not only done to create the best technology or system, but in this case, it is essential whether the Smart Governance is acceptable by users of the City Government and Society Bandung. Smart City is a field of research selected by the author in which several models and theories have been proposed to know the indicators of Smart City implementation, especially in the field of Smart Governance in the city of Bandung.

Based on the formulation of the above problems, it could determine that the purpose of this study are as follows:

1. Knowing and collecting the most appropriate dimensions and indicators in Smart Governance measurement in Bandung City.

2. Getting interview results and focus group discussion about the dimensions and indicators that can be used to measure Smart Governance in Bandung.

3. To get the statement items which can be used to measure Smart Governance in Bandung City.

The formulation of the issues to be raised as research material for this thesis is as follows:

1. Based on the literature review, what dimensions and indicators are appropriate to measure Smart Governance in Bandung?

2. Based on the interview or focus group discussion, what dimensions and indicators can be used to measure Smart Governance in Bandung?

3. What statement items are formed from a questionnaire that can be used to measure or identify the implementation of Smart Governance in Bandung? 
4. What are the advantages of determining the dimensions and indicators of Smart Governance implementation in Bandung?

\section{RESEARCH METHODOLOGY}

Research conducted to get dimensions and indicators of Smart Governance is included the type of research Qualitative then for the method used is the Explorative Method. Explorative research results rely on secondary research such as reviewing the available literature and qualitative approach data such as informal discussions with consumers, employees, competitor companies, and more approaches formal through in-depth interviews through case studies or focus group discussions to business players and management experts.

In this case, the authors formulate the operational variables based on dimensions and indicators that are the result of the exploration of literature studies on Smart Governance dimensions and indicators that have been formulated by various parties.

This research is conducted by the following research stages to be directed and systematic.

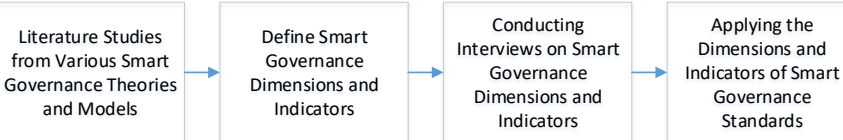

Figure 4. Research Stages

The literature study is a search for relevant theory references and which will be used in a study. The theoretical reference to this research covers the application of Smart City and Smart Governance. Indrawati mentions that literature studies can be obtained from various sources that can be accounted for, such as journal proceeding, expert opinions (e.g., consultants), opinions from stakeholders (stakeholder), textbook, and any other references [17]. Derived from previous research and after the grouping and selection of Smart Governance dimensions, the authors decided to take from 15 references related dimensions that will be used as variables in this study. Table 1 shows the Variable/Dimensions and Indicator from the literature review [18].

Table 1. Smart Governance Variables Based on Literature Study

\begin{tabular}{|c|c|c|c|}
\hline No & Sources / References & $\begin{array}{c}\text { No } \\
\text { Dimension }\end{array}$ & $\begin{array}{c}\text { Dimension/Variable Smart } \\
\text { Governance }\end{array}$ \\
\hline \multirow[t]{2}{*}{1} & $\begin{array}{l}\text { A. International } \\
\text { Telecommunication } \\
\text { Union - T }\end{array}$ & A.D1 & $\begin{array}{l}\text { D5.3 Openness and public } \\
\text { participation }\end{array}$ \\
\hline & & A.D2 & D5.4 Governance \\
\hline \multirow[t]{13}{*}{2} & $\begin{array}{l}\text { B. Smart City Expo } \\
\text { World Congress }\end{array}$ & B.D1 & Open government \\
\hline & & B.D2 & Transparency \\
\hline & & B.D3 & Open data \\
\hline & & B.D4 & Procurement process \\
\hline & & B.D5 & $\begin{array}{l}\text { New public-private collaboration } \\
\text { frameworks }\end{array}$ \\
\hline & & B.D6 & Financial instruments \\
\hline & & B.D7 & Public services \\
\hline & & B.D8 & Innovation networks \\
\hline & & B.D9 & Performance measurement \\
\hline & & B.D10 & Urban resilience \\
\hline & & B.D11 & $\begin{array}{l}\text { Customization of service } \\
\text { provision }\end{array}$ \\
\hline & & B.D12 & Circular economy \\
\hline & & B.D13 & Service integration policies \\
\hline
\end{tabular}

\begin{tabular}{|c|c|c|c|}
\hline No & Sources / References & $\begin{array}{c}\text { No } \\
\text { Dimension }\end{array}$ & $\begin{array}{c}\text { Dimension/Variable Smart } \\
\text { Governance }\end{array}$ \\
\hline & & B.D14 & Regulations \& business models \\
\hline \multirow[t]{4}{*}{3} & $\begin{array}{l}\text { C. United Nations- } \\
\text { Habitat }\end{array}$ & C.D1 & Productivity \\
\hline & & C.D2 & Quality of life \\
\hline & & C.D3 & Infrastructure development \\
\hline & & C.D4 & Environmental sustainability \\
\hline \multirow[t]{4}{*}{4} & $\begin{array}{l}\text { D. China Institute of } \\
\text { Communications (CIC) }\end{array}$ & D.D1 & Information infrastructure \\
\hline & & D.D2 & Smart applications \\
\hline & & D.D3 & Support system \\
\hline & & D.D4 & Value implementation \\
\hline \multirow[t]{4}{*}{5} & $\begin{array}{l}\text { E. Ministry of Housing } \\
\text { and Urban-Rural } \\
\text { Development China }\end{array}$ & E.D1 & $\begin{array}{l}\text { Guarantee system and } \\
\text { infrastructure }\end{array}$ \\
\hline & & E.D2 & Smart construction and livability \\
\hline & & E.D3 & Smart governance and service \\
\hline & & E.D4 & Smart industry and economy \\
\hline \multirow[t]{5}{*}{6} & $\begin{array}{l}\text { F. Index system of smart } \\
\text { city and smart statistics } \\
\text { (Italy) }\end{array}$ & F.D1 & $\begin{array}{l}\text { 3.1.1 Level of digital services } \\
\text { provided by smart city (e.g.: fee } \\
\text { payment for applications on } \\
\text { mobile phones or via the web) }\end{array}$ \\
\hline & & F.D2 & $\begin{array}{l}\text { 3.1.2 Level of emergency } \\
\text { warning systems (through mobile } \\
\text { phones and online) }\end{array}$ \\
\hline & & F.D3 & $\begin{array}{l}\text { 3.1.3 Level of decision-making } \\
\text { online system offered by the city } \\
\text { (e.g., polls, referendums, etc.)* }\end{array}$ \\
\hline & & F.D4 & $\begin{array}{l}\text { 3.2.1 Percentage of citizens who } \\
\text { use digital services (e.g., fee } \\
\text { payment for applications on } \\
\text { mobile phones or via the web) }\end{array}$ \\
\hline & & F.D5 & $\begin{array}{l}\text { 3.2.2 Percentage of citizens' } \\
\text { participation in online decision- } \\
\text { making (through polls, } \\
\text { referendums, etc.)* }\end{array}$ \\
\hline \multirow[t]{6}{*}{7} & $\begin{array}{l}\text { G. Indicators of The } \\
\text { Emerging and } \\
\text { Sustainable Cities } \\
\text { Initiative (ESCI) }\end{array}$ & G.D1 & $\begin{array}{l}\text { R. Participatory public } \\
\text { management }\end{array}$ \\
\hline & & G.D2 & S. Modern public management \\
\hline & & G.D3 & T. Transparency \\
\hline & & G.D4 & U. Taxes and financial autonomy \\
\hline & & G.D5 & V. Expenditure management \\
\hline & & G.D6 & W. Debt \\
\hline \multirow[t]{5}{*}{8} & H. Kardos (2012) & H.D1 & Accountability, \\
\hline & & H.D2 & Transparency, \\
\hline & & H.D3 & Efficiency \\
\hline & & H.D4 & The rule of law at all levels \\
\hline & & H.D5 & $\begin{array}{l}\text { Allows efficient management of } \\
\text { human, natural, economic, } \\
\text { financial resources and } \\
\text { guaranteeing civil society } \\
\text { participation in decision-making } \\
\text { processes }\end{array}$ \\
\hline \multirow[t]{4}{*}{9} & $\begin{array}{l}\text { I. Designing Next } \\
\text { Generation Smart City } \\
\text { Initiatives }\end{array}$ & I.D1 & Coordination and integration \\
\hline & & I.D2 & Service integration \\
\hline & & I.D3 & Participation and coproduction \\
\hline & & I.D4 & Policy and regulations \\
\hline \multirow[t]{4}{*}{10} & $\begin{array}{l}\text { J. European Ranking of } \\
\text { Medium-sized Cities } \\
\text { (VUT) }\end{array}$ & J.D1 & Participation in decision-making \\
\hline & & J.D2 & Public and social services \\
\hline & & J.D3 & Transparent governance \\
\hline & & J.D4 & $\begin{array}{l}\text { Political strategies and } \\
\text { perspectives }\end{array}$ \\
\hline \multirow[t]{3}{*}{11} & K. Smart Cities Wheel & K.D1 & $\begin{array}{l}\text { Enabling supply and demand } \\
\text { side policy }\end{array}$ \\
\hline & & K.D2 & Transparency and open data \\
\hline & & K.D3 & ICT and e-government \\
\hline 12 & $\begin{array}{l}\text { L. Smarter City } \\
\text { Assessment (IBM) }\end{array}$ & L.D1 & $\begin{array}{l}\text { Local government } \\
\text { expenditure/budget }\end{array}$ \\
\hline
\end{tabular}




\begin{tabular}{|c|c|c|c|}
\hline No & Sources / References & $\begin{array}{c}\text { No } \\
\text { Dimension }\end{array}$ & $\begin{array}{c}\text { Dimension/Variable Smart } \\
\text { Governance }\end{array}$ \\
\hline & & L.D2 & Local government staff \\
\hline & & L.D3 & $\begin{array}{l}\text { Strategic planning and } \\
\text { performance measurement }\end{array}$ \\
\hline & & L.D4 & Integrated information system \\
\hline & & L.D5 & E-government \\
\hline & & L.D6 & $\begin{array}{l}\text { Efficiency and effectiveness of } \\
\text { service delivery }\end{array}$ \\
\hline \multirow[t]{4}{*}{13} & $\begin{array}{l}\text { M. Index system of } \\
\text { Smart Sustainable City }\end{array}$ & M.D1 & Communication \\
\hline & & M.D2 & Sustainable behavior \\
\hline & & M.D3 & Environment protection policy \\
\hline & & M.D4 & e-Services \\
\hline \multirow[t]{7}{*}{14} & $\begin{array}{l}\text { N. Giffinger's (2007) dan } \\
\text { Cohehen (2013) }\end{array}$ & N.D1 & $\begin{array}{l}\text { Participation in decision- } \\
\text { making; }\end{array}$ \\
\hline & & N.D2 & Public and social services \\
\hline & & N.D3 & Transparent governance \\
\hline & & N.D4 & $\begin{array}{l}\text { Political strategies \& } \\
\text { Perspectives }\end{array}$ \\
\hline & & N.D5 & Demand policy \\
\hline & & N.D6 & Transparency \& open data \\
\hline & & N.D7 & ICT \& government \\
\hline \multirow[t]{3}{*}{15} & $\begin{array}{l}\text { Citiasia Center for Smart } \\
\text { Nation }\end{array}$ & O.D1 & Bureaucracy \\
\hline & & O.D2 & Policy \\
\hline & & O.D3 & Service \\
\hline
\end{tabular}

At this stage, the author is screening and grouping of definitions derived from the literature search results. Determining the dimensions and indicators should be done carefully so as not to cause bias that can confuse the author himself. The dimensions and indicators from the literature review are collected, and it is selected based on the primarily connected to the Smart Governance issue. The author as a primary tool which will do the dimensions and variable selection and the author must have the information about the Smart Governance indicators from many references. Table 2 showing the dimensions and indicator from the literature, which is primarily related to the Smart Governance specifically for the eGovernance issues.

Table 2. Variable and Indicators of Smart Governance Primarily related to e-Governance

\begin{tabular}{|l|l|l|}
\hline No & \multicolumn{1}{|c|}{$\begin{array}{c}\text { No. } \\
\text { Dimensions }\end{array}$} & \multicolumn{1}{|c|}{$\begin{array}{c}\text { Variable and Indicators of Smart Governance Primarily } \\
\text { related to e-Governance }\end{array}$} \\
\hline 1 & A.D1 & Variable Openness and Public Participations \\
\hline 1.1 & A.D1.1 & $\begin{array}{l}\text { Availability of online city information and feedback } \\
\text { mechanisms }\end{array}$ \\
\hline 1.2 & A.D1.2 & Online civic engagement \\
\hline 1.3 & A.D1.3 & Online support for new city inhabitants \\
\hline 1.4 & A.D1.4 & $\begin{array}{l}\text { Existence of strategies, rules, and regulations to enable ICT } \\
\text { literacy among inhabitants }\end{array}$ \\
\hline 2 & A.D2 & Variable e-Governance \\
\hline 2.1 & A.D2.1 & $\begin{array}{l}\text { Provision of online systems for administering public services } \\
\text { and facilities }\end{array}$ \\
\hline 2.2 & A.D2.2 & $\begin{array}{l}\text { Application of services to support persons with specific } \\
\text { needs }\end{array}$ \\
\hline 3 & B.D5 & Variable New Public-Private Collaboration Frameworks \\
\hline 4 & D.D2 & Variable Smart Applications \\
\hline 4.1 & D.D2.1 & Support degree of information resource on decision-making \\
\hline 5 & D.D3 & Variable Support System \\
\hline 5.1 & D.D3.2 & Complete rate of information standards \\
\hline 6 & E.D1 & Variable Guarantee System \\
\hline 6.1 & E.D1.1 & Smart city plan and implementation scheme \\
\hline 6.2 & E.D2.2 & Organization guarantee \\
\hline 7 & G.D1 & Variable Participatory Public Management \\
\hline 7.1 & G.D1.1 & Public reporting sessions per year \\
\hline 8 & G.D2.1 & $\begin{array}{l}\text { Variable Modern Processes of Public Management of The } \\
\text { Municipal Budget }\end{array}$ \\
\hline 8.1 & G.D2.1.1 & Existence of a multi-annual budget \\
\hline 8.2 & G.D2.1.2 & $\begin{array}{l}\text { Remuneration of personnel based on a system of } \\
\text { performance indicators }\end{array}$ \\
\hline
\end{tabular}

\begin{tabular}{|l|l|l|}
\hline No & \multicolumn{1}{|c|}{$\begin{array}{c}\text { No. } \\
\text { Dimensions }\end{array}$} & \multicolumn{1}{|c|}{$\begin{array}{c}\text { Variable and Indicators of Smart Governance Primarily } \\
\text { related to e-Governance }\end{array}$} \\
\hline 9 & G.D2.2 & $\begin{array}{l}\text { Variable Modern Systems of Public Management of The } \\
\text { Municipal Government }\end{array}$ \\
\hline 9.1 & G.D2.2.1 & $\begin{array}{l}\text { Existence of electronic systems for tracking the } \\
\text { municipality's management }\end{array}$ \\
\hline 9.2 & G.D2.2.2 & Existence of electronic procurement system \\
\hline 10 & G.D3.1 & $\begin{array}{l}\text { Variable Transparency and Auditing of The Government's } \\
\text { Public Management }\end{array}$ \\
\hline 10.1 & G.D3.1.1 & Transparency index \\
\hline 10.2 & G.D3.1.2 & Municipal government accounts audited \\
\hline 10.3 & G.D3.1.3 & Municipal companies' accounts audited by a third party \\
\hline 11 & H.D3 & Variable Efficiency \\
\hline 12 & I.D1 & Variable Coordination and Integration \\
\hline 12.1 & I.D1.5 & Integration of policy implementation in multiple dimensions \\
\hline 13 & I.D3 & Variable Participation and Coproduction \\
\hline 13.1 & I.D3.2 & Information exchange \\
\hline 14 & L.D2 & Variable Local Government Staff \\
\hline 15 & O.D1 & Variable Bureaucracy \\
\hline 15.1 & O.D1.1 & Accountability \\
\hline 15.2 & O.D2.2 & Fairness \\
\hline
\end{tabular}

The process of in-depth interview is the process of obtaining information for research through question and answer between the interviewer with the respondent or the person being interviewed. In qualitative research, the depth interview technique is often used to confirm the data already obtained from previous literature studies. The interview is also a tool to check or verify information or information obtained previously and also a direct communication technique between researchers and respondents. In this case, the in-depth interview method is done with the list of questions that have been prepared before.

This process is done by proposing dimensions and indicators related to Smart Governance research, which is the final process of this research stage. Where dimensions and indicators obtained from literature studies have been confirmed and analyzed in advance by conducting in-depth interviews/focus group discussions by practitioners, business players, stakeholders, and users related to Smart Governance implementation.

In qualitative research, sample determination is done by selecting respondents who are considered to know the topic and problems in depth and can be trusted to find a stable and complete data source. The sampling method used in this study uses a purposive sampling method in which the sample is selected from government, business player, users/customers, and researchers/observers, and experts.

\section{Table 3. Respondent Criteria}

\begin{tabular}{|c|l|c|}
\hline No & \multicolumn{1}{|c|}{ Respondent Criteria } & $\begin{array}{c}\text { Number of } \\
\text { Respondent }\end{array}$ \\
\hline 1 & Business Player/ User & 10 persons \\
\hline 2 & Government & 10 persons \\
\hline 3 & Researchers/ Observers/ Experts & 10 persons \\
\hline
\end{tabular}

\section{SMART GOVERNANCE (E-GOVERNANCE) CRITERIA: LITERATURE REVIEW RESULT}

After doing the interview and the focus group discussion, the result of the respondent confirmation is coded to the list of the variables and indicators. Table 4 shows the variables based on the literature which have been coded from the interview and the focus group discussions.

Table 4. Variable Based on the Literature Coded

\begin{tabular}{|l|l|c|c|}
\hline No & \multicolumn{1}{|c|}{ Variable / Indicator } & Coded & $\begin{array}{c}\text { Percentage } \\
\text { of } \\
\text { Confirmation }\end{array}$ \\
\hline 1 & Variable Openness and Public Participations & & \\
\hline 1.1 & $\begin{array}{l}\text { Availability of online city information and } \\
\text { feedback mechanisms }\end{array}$ & 21 & $80 \%$ \\
\hline
\end{tabular}




\begin{tabular}{|c|c|c|c|}
\hline No & Variable / Indicator & Coded & $\begin{array}{c}\text { Percentage } \\
\text { of } \\
\text { Confirmation }\end{array}$ \\
\hline 1.2 & Online civic engagement & 24 & $96 \%$ \\
\hline 1.3 & Online support for new city inhabitants & 1 & $4 \%$ \\
\hline 1.4 & $\begin{array}{l}\text { Existence of strategies, rules, and regulations to } \\
\text { enable ICT literacy among inhabitants }\end{array}$ & 27 & $80 \%$ \\
\hline 2 & Variable e-Governance & & \\
\hline 2.1 & $\begin{array}{l}\text { Provision of online systems for administering } \\
\text { public services and facilities }\end{array}$ & 40 & $100 \%$ \\
\hline 2.2 & $\begin{array}{l}\text { Application of services to support persons with } \\
\text { specific needs }\end{array}$ & 13 & $40 \%$ \\
\hline 3 & $\begin{array}{l}\text { Variable New Public-Private Collaboration } \\
\text { Frameworks }\end{array}$ & 28 & $92 \%$ \\
\hline 4 & Variable Smart Applications & & \\
\hline 4.1 & $\begin{array}{l}\text { Support degree of information resource on } \\
\text { decision-making }\end{array}$ & 11 & $64 \%$ \\
\hline 5 & Variable Support System & & \\
\hline 5.1 & Complete rate of information standards & 6 & $48 \%$ \\
\hline 6 & Variable Guarantee System & & \\
\hline 6.1 & Smart city plan and implementation scheme & 46 & $100 \%$ \\
\hline 6.2 & Organization guarantee & 19 & $96 \%$ \\
\hline 7 & Variable Participatory Public Management & & \\
\hline 7.1 & Public reporting sessions per year & 2 & $36 \%$ \\
\hline 8 & $\begin{array}{l}\text { Variable Modern Processes of Public } \\
\text { Management of The Municipal Budget }\end{array}$ & & \\
\hline 8.1 & Existence of a multi-annual budget & 10 & $84 \%$ \\
\hline 8.2 & $\begin{array}{l}\text { Remuneration of personnel based on a system of } \\
\text { performance indicators }\end{array}$ & 5 & $16 \%$ \\
\hline 9 & $\begin{array}{l}\text { Variable Modern Systems of Public Management } \\
\text { of The Municipal Government }\end{array}$ & & \\
\hline 9.1 & $\begin{array}{l}\text { Existence of electronic systems for tracking the } \\
\text { municipality's management }\end{array}$ & 33 & $100 \%$ \\
\hline 9.2 & Existence of electronic procurement system & 9 & $60 \%$ \\
\hline 10 & $\begin{array}{l}\text { Variable Transparency and Auditing of The } \\
\text { Government's Public Management }\end{array}$ & & \\
\hline 10.1 & Transparency index & 12 & $52 \%$ \\
\hline 10.2 & Municipal government accounts audited & 4 & $40 \%$ \\
\hline 10.3 & $\begin{array}{l}\text { Municipal companies' accounts audited by a third } \\
\text { party }\end{array}$ & 1 & $8 \%$ \\
\hline 11 & Variable Efficiency & 16 & $60 \%$ \\
\hline 12 & Variable Coordination and Integration & & \\
\hline 12.1 & $\begin{array}{l}\text { Integration of policy implementation in multiple } \\
\text { dimensions }\end{array}$ & 40 & $100 \%$ \\
\hline 13 & Variable Participation and Coproduction & & \\
\hline 13.1 & Information exchange & 24 & $80 \%$ \\
\hline 14 & Variable Local Government Staff & 36 & $100 \%$ \\
\hline 15 & Variable Bureaucracy & & \\
\hline 15.1 & Accountability & 4 & $28 \%$ \\
\hline 15.2 & Fairness & 2 & $12 \%$ \\
\hline
\end{tabular}

There are variables and indicators which is coded or confirmed by the respondent but not getting more than $50 \%$; these variables or indicators will be eliminated and stated as unconfirmed variables and indicators.

\section{SMART GOVERNANCE (E-GOVERNANCE) CRITERIA: BASED ON INTERVIEW \& FGD RESULT}

The result of the eliminations of the unconfirmed variables and indicators are shown in Table 5. This variables and indicators also stated as the confirmed variables and indicators which have been confirmed by the respondent of this research.

Table 5. Variable Based on Interview \& FGD Result

\begin{tabular}{|l|l|c|c|}
\hline No & \multicolumn{1}{|c|}{ Variable / Indicator } & Coded & $\begin{array}{c}\% \\
\text { Confirmation }\end{array}$ \\
\hline 1 & $\begin{array}{l}\text { Variable Openness and Public } \\
\text { Participations }\end{array}$ & 21 & $80 \%$ \\
\hline 1.1 & $\begin{array}{l}\text { Availability of online city information } \\
\text { and feedback mechanisms }\end{array}$ & 24 & $96 \%$ \\
\hline 1.2 & Online civic engagement & 27 & $80 \%$ \\
\hline 1.3 & $\begin{array}{l}\text { Existence of strategies, rules, and } \\
\text { regulations to enable ICT literacy among } \\
\text { inhabitants }\end{array}$ & & \\
\hline 2 & Variable e-Governance & & \\
\hline
\end{tabular}

\begin{tabular}{|c|c|c|c|}
\hline No & Variable / Indicator & Coded & $\begin{array}{c}\% \\
\text { Confirmation }\end{array}$ \\
\hline 2.1 & $\begin{array}{l}\text { Provision of online systems for } \\
\text { administering public services and } \\
\text { facilities }\end{array}$ & 40 & $100 \%$ \\
\hline 3 & $\begin{array}{l}\text { Variable New Public-Private } \\
\text { Collaboration Frameworks }\end{array}$ & 28 & $92 \%$ \\
\hline 4 & Variable Smart Applications & & \\
\hline 4.1 & $\begin{array}{l}\text { Support degree of information resource } \\
\text { on decision-making }\end{array}$ & 11 & $64 \%$ \\
\hline 5 & Variable Guarantee System & & \\
\hline 5.1 & $\begin{array}{l}\text { Smart city plan and implementation } \\
\text { scheme }\end{array}$ & 46 & $100 \%$ \\
\hline 5.2 & Organization guarantee & 19 & $96 \%$ \\
\hline 6 & $\begin{array}{l}\text { Variable Modern Processes of Public } \\
\text { Management of The Municipal Budget }\end{array}$ & & \\
\hline 6.1 & Existence of a multi-annual budget & 10 & $84 \%$ \\
\hline 7 & $\begin{array}{l}\text { Variable Modern Systems of Public } \\
\text { Management of The Municipal } \\
\text { Government }\end{array}$ & & \\
\hline 7.1 & $\begin{array}{l}\text { Existence of electronic systems for } \\
\text { tracking the municipality's management }\end{array}$ & 33 & $100 \%$ \\
\hline 7.2 & $\begin{array}{l}\text { Existence of electronic procurement } \\
\text { system }\end{array}$ & 9 & $60 \%$ \\
\hline 8 & $\begin{array}{l}\text { Variable Transparency and Auditing of } \\
\text { The Government's Public Management }\end{array}$ & & \\
\hline 8.1 & Transparency index & 12 & $52 \%$ \\
\hline 9 & Variable Efficiency & 16 & $60 \%$ \\
\hline 10 & Variable Coordination and Integration & & \\
\hline 10.1 & $\begin{array}{l}\text { Integration of policy implementation in } \\
\text { multiple dimensions }\end{array}$ & 40 & $100 \%$ \\
\hline 11 & Variable Participation and Coproduction & & \\
\hline 11.1 & Information exchange & 24 & $80 \%$ \\
\hline 12 & Variable Local Government Staff & 36 & $100 \%$ \\
\hline
\end{tabular}

\section{CONCLUSION}

The results of this study determined that the implementation of Smart Governance, particularly for e-Governance, has found 12 variables and 13 indicators. The model for measuring Smart Governance presented in Figure 5.

Suggestions for the Central Government

1. The results of this study are Smart Governance variables and indicators which is used as a reference in the development or implementation of Smart Governance in Bandung City and other cities in Indonesia.

2. The central government should issue rules or policies that encourage the development of Smart Governance, for example:

a. Create a blueprint and ICT governance to support Smart Governance to be implemented throughout the city.

b. Collaborate with international stakeholders on the development phase and implementation of Smart Governance.

3. The central government should be able to be functioned as a Smart Governance integrator so that the central government can also access the data and make the data for national or regional decision-making.

4. The central government can organize and control Smart Governance roadmap for implementation in many cities.

5. The Government should give socialization for the public to support people in understanding the policy gradually and comprehensively. A reciprocal obligation needs to be provided from the central government and the local government to implement Smart Governance optimally. 
6. The central government can provide reward and motivation for the other cities which have started to implement Smart Governance.

Suggestions for Bandung City Government:

1. Bandung has a vast number of applications that support Smart Governance; it is enough to be used to manage the city of Bandung to become smarter. The next stage requires the integration of Smart Governance applications to be more integrated and structured in the future.

2. Considerations related to security are required from these applications so that data and information to be exchanged could be guaranteed securely. Bandung City needs to collaborate with private parties to improve by using many alternative ways of making these applications becoming optimal for Bandung's decision making systems.

3. Bandung City Government needs to implement in various ways to disseminate information for the public regarding Smart Governance applications, and also the participation from the community will help improve the accuracy and results of the use of Smart Governance applications.

Suggestions for Businesses:

To implement Smart Governance concept in Bandung City, it requires the availability of the device, system, and supporting software. The market potential of Smart Governance has a very high economic value. Businesses entities (e.g., operators, suppliers, consultants, and even principal) may refer to the standardization that turns out to be the reference in Smart Governance. The business entity must also have high integrity in realizing the success of Smart Governance implementation, not only make it as a commodity but require to prioritize the progress of the development of health, quality improvement, comfort, convenience to users and society.

Suggestions for Academics:

This research has determined variables and indicators of Smart Governance; for further analysis, it is used to assess The Smart Governance of a city by doing a pilot test to each item produced by this research. This assessment can be used to calculate the index of preparedness of the city government in applying Smart Governance. The evaluation will define the level of city readiness in implementing The Smart City.

Smart City, in general, and Smart Governance, in particular, is a very dynamic science. Further research is needed to continue in accommodating parameters in the ecosystem, including the peoples, processes, and technologies that will continue to evolve according to the demands of the times.

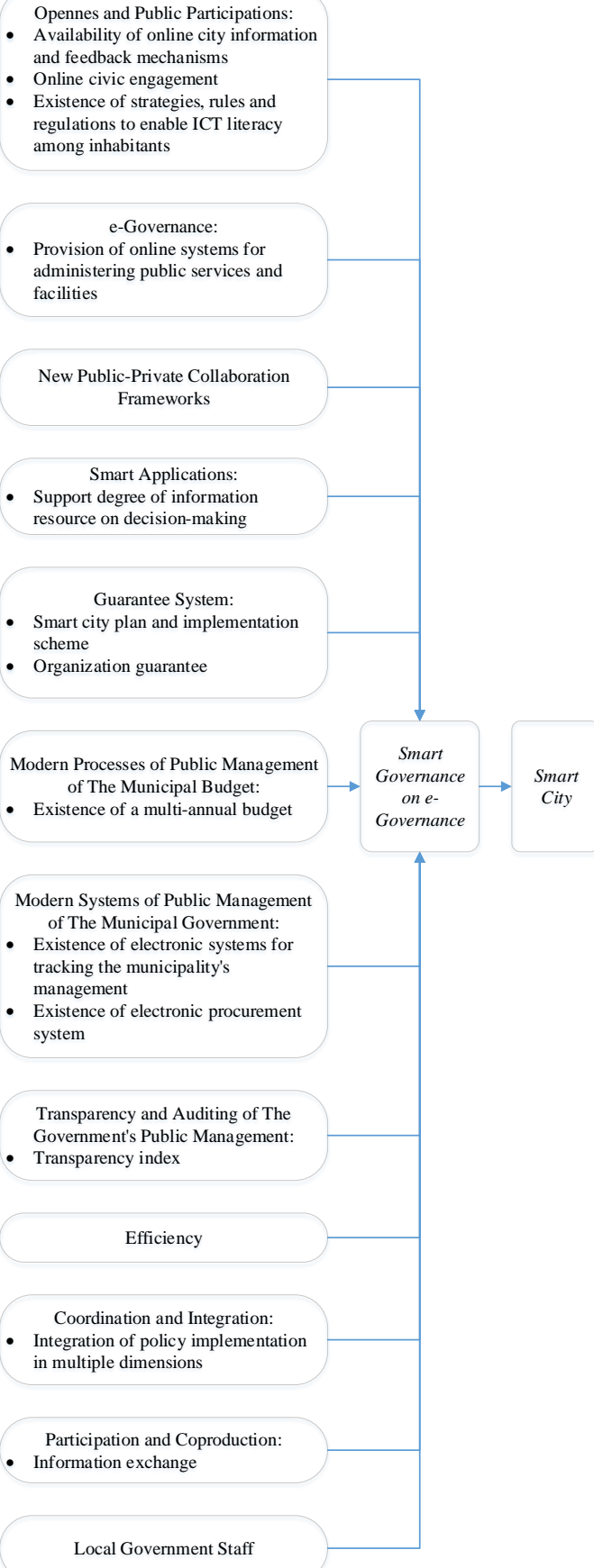

Figure 5. Proposed Models of Smart Governance (eGovernance)

\section{REFERENCES}

[1] Termanini D R 2015 The Cognitive Early Warning Predictive System Using the Smart Vaccine (New York: Auerbach)

[2] Ericsson 2016 5G Readiness Survey 1-8

[3] Department of Economic and Social Affairs U N 2014 Population Division (2014): World Urbanization Prospects: The 2014 Revision

[4] Utoyo S 2015 Statistik Perusahaan Informasi dan Komunikasi 2015 Katalog BPS 8305004 1-125

[5] APJII 2016 Survey Penetrasi dan Perilaku Pengguna Internet Indonesia 2016 (Jakarta) 
[6] Badan Pusat Statistik 2016 Statistik Indonesia 2016 ed Subdirektorat Publikasi dan Kompilasi Statistik (Jakarta: Badan Pusat Statistik)

[7] Amaliya 2016 Forum Smart City, Ajang Berbagi Teknologi Pikiran Rakyat

[8] REPUBLIKA.CO.ID 201519 Inovasi Ridwan Kamil Kala Mereformasi Birokrasi Bandung | Republika Online

[9] Kamil R 2016 Bandung Smart City 37

[10] BIROKRASINEWS.COM 2016 Bandung Smart City, Solusi Permasalahan Publik di Kota Bandung BirokrasiNews.com

[11] Ardisasmita A 2015 Langkah Bandung Dalam Mengimplementasikan Smart City 1-7

[12] Singh S 2014 Smart Cities: A USD1.5 Trillion Market Opportunity 4

[13] Kardos M 2012 The Reflection of Good Governance in Sustainable Development Strategies Procedia - Soc. Behav. Sci. 58 1166-73

[14] Scuotto V, Ferraris A and Bresciani S 2016 Internet of Things: Applications and challenges in smart cities: a case study of IBM smart city projects Bus. Process Manag. J. 22 357-67

[15] Komninos N, Pallot M and Schaffers H 2013 Special Issue on Smart Cities and the Future Internet in Europe $J$. Knowl. Econ. 4 119-34

[16] Smart City ID 2015 Smart Community For Smart City Indonesia I 6

[17] Indrawati Ph.D. 2015 Metode Penelitian Manajemen dan Bisnis (Bandung: Refika Aditama)

[18] ITU T S S O 2015 Key performance indicators definitions for smart sustainable cities 